\title{
Pengaruh Temperatur Aniling Material MgAITi Terhadap Media Penyimpan Hidrogen
}

\author{
Sabtun Ismi Khasanah ${ }^{1)^{\star}}$, Nandha Riveri Sesunan ${ }^{2)}$ \\ ${ }^{1,2)}$ Program Studi Teknologi Pengecoran Logam, Politeknik Manufaktur Ceper
}

\author{
Naskah diterima 05 Agustus 2019; direvisi 22 September 2019; disetujui 28 Oktober 2019 \\ doi: https://doi.org/10.24843/JEM.2019.v12.i02.p07
}

\begin{abstract}
Abstrak
Hidrogen merupakan salah satu sumber energi alternatif di masa depan. Penyimpanan Hidrogen dalam bentuk solid state memiliki keunggulan daripada penyimpanan dalam bentuk gas dan cair. Penelitian ini dilakukan untuk mempelajari pengaruh material MgAITi dan temperatur aniling material (MgAITi) hasil preparasi reactive mechanical alloying (RMA) terhadap sifat media penyimpan hidrogen. Penambahan paduan logam Al dan Ti pada paduan logam $\mathrm{Mg}$ dilakukan untuk memperbaiki sifat serapan Mg. Penelitian dilakukan dengan memadukan material Mg, Al dan Ti dengan komposisi berat berturut-turut 85,15 dan $5 \%$. Ketiga logam dipadukan dengan teknik RMA. Persiapan pemaduan dilakukan dalam glove box yang dialiri gas argon untuk memastikan pengerjaan teknik RMA dalam keadaan inert. Pemaduan teknik RMA dilakukan selama 10 jam dengan dialiri gas Hidrogen. Selanjutnya, paduan $\mathrm{Mg}_{85} \mathrm{Al}_{15}+\mathrm{Ti}_{5}$ di anil dengan variasi temperatur pemanasan $300 ; 340 ;$ dan $380{ }^{\circ} \mathrm{C}$. Karakterisasi struktur kristal, mikro dan termal uji diobservasi dengan menggunakan X-Ray Difraction, SEM-EDX dan Differential Scanning Calorimetry (DSC). Hasil analisis struktur kristal dan mikro sesudah di aniling menjadi homogen dan hasil ini menunjukkan bahwa temperatur optimum material penyimpan hidrogen terjadi pada temperatur $300{ }^{\circ} \mathrm{C}$. Aktifitas katalis terhadap disosiasi ikatan $\mathrm{Mg}-\mathrm{H}_{2}$ dapat menentukan penurunan temperatur desorpsi dibandingkan pengaruh temperatur aniling. Pemaduan teknik RMA pada paduan logam MgAITi dapat meningkatkan sifat-sifat penyimpanan hidrogen.
\end{abstract}

Kata kunci: Media penyimpan hidrogen, reactive mechanical alloying (RMA), aniling

\begin{abstract}
Hydrogen is an alternative energy source and it has advantages to storage the element in form of solid state compare gas and liquid. The study was conducted to analyse the effect of MgAlTi in aniling temperature used reactive mechanical alloying (RMA) for hydrogen storage. The experimental was carried out to improve the absorption $\mathrm{Mg}$ by combination of $\mathrm{Mg}$, Al and $\mathrm{Ti}$ materials with 85, 15 and 5\% weight composition. The preparation is carried out in the glove box which is flowed with argon gas to ensure the work of the RMA technique in an inert state. The RMA techniques is carried out for 10 hours with Hydrogen gas flowing. Thus, the Mg85Al15 + Ti5 alloy is annealed with a heating temperature variation of 300; 340; and 380 ${ }^{\circ} \mathrm{C}$. Characterization of crystal structure, micro and thermal tests were observed using X-Ray Difraction, SEM-EDX and Differential Scanning Calorimetry (DSC). The results of analysis of the crystal and micro structures after aniling become homogeneous and this shows that the optimum temperature of the hydrogen storage material occurs at a temperature of $300{ }^{\circ} \mathrm{C}$. Moreover, the catalyst activity against dissociation of $\mathrm{Mg}-\mathrm{H}_{2}$ bonds can determine the decrease in desorption temperature compared to the effect of aniling temperature. The integration of RMA techniques in MgAlTi metal alloys can improve hydrogen storage.
\end{abstract}

Keywords: Hydrogen storage, solid state, reactive mechanical alloying (RMA), aniling

\section{Pendahuluan}

Penggunaan bahan bakar fosil melepaskan gas efek rumah kaca yang menyebabkan peningkatan pemanasan global. Sumber energi terbarukan yang bersifat ramah lingkungan perlu dikembangkan untuk mengatasi permasalahan tersebut. Hidrogen memiliki potensial besar sebagai energi alternatif karena kelimpahannya tinggi, ringan, menghasilkan pembakaran panas tinggi, reprodusibel, dan emisi non polutan atau ramah lingkungan selama pembakaran. Hidrogen dapat dikonversi menjadi energi listrik dengan bantuan sistem sel bahan bakar atau dikenal dengan fuel cell. Hidrogen bereaksi dengan oksigen di dalam fuel cell menghasilkan listrik. Hasil samping reaksi tersebut hanya berupa uap air sehingga dapat dikatakan hidrogen sangat ramah lingkungan [1].

Hidrogen dapat disimpan dalam bentuk gas, cair maupun padat. Berbagai teknologi penyimpanan gas hidrogen telah dikembangkan dengan mempertimbangkan biaya, berat dan volume, efisiensi, keawetan, waktu pengisian dan pengosongan, temperatur kerja serta efisiensinya [1][2]. Media penyimpanan hidrogen berbentuk padatan memiliki kelebihan dibandingkan media penyimpanan berbentuk gas maupun cair. Hidrogen dalam bentuk gas harus disimpan dalam tangki bertekanan tinggi antara 200-700 bar, sedangkan hidrogen dalam bentuk cair harus dijaga agar tetap dalam keadaan cair pada temperature $\left(-253^{\circ} \mathrm{C}\right)$. Kedua metode ini belum menjanjikan dalam sisi keamanan [3]. Hidrida logam memilki tingkat kepadatan penyimpanan hidrogen yang tinggi $\left(6,5\right.$ atom $/ \mathrm{cm}^{3}$ untuk $\left.\mathrm{MgH}_{2}\right)$ daripada dalam bentuk gas hidrogen $(0,99$ atom $/ \mathrm{cm} 3$ ) atau hidrogen cair $\left(4,2\right.$ atom $\left./ \mathrm{cm}^{3}\right)$. Penyimpanan hidrogen dalam bentuk hidrida logam yaitu atom-atom hidrogen disimpan di dalam kisi material utamanya dan akan dilepas dengan adanya stimulasi panas atau dengan teknik yang lain [4].

Magnesium mampu menampung hidrogen sebesar $7,6 \%$ berat logam, artinya apabila magnesium digunakan sebagai media simpan hidrogen, maka diperlukan magnesium seberat $39,5 \mathrm{~kg}$ dengan volume sebesar 22,7 liter. Kemampuan magnesium dalam menyimpan hidrogen $7,6 \%$ berat logam menjadi salah satu kandidat potensial sebagai material penyerap hidrogen. Jumlah ini melebihi batas maksimum yang ditargetkan Badan Energi Dunia sebesar 5\% [5]. Hasil penelitian menyatakan bahwa 
kapasitas penyerapan hidrogen untuk material $\mathrm{MgH}_{2}-\mathrm{TiH}_{2}$ dan $\mathrm{MgH}_{2}-\mathrm{SiC}$ sebesar 6\%, dan 6,3\% [6]. Magnesium sebagai logam penyimpan hidrogen memiliki beberapa kekurangan yaitu stabilitas termodinamika tinggi. Stabilitas termodinamika yang tinggi menghasilkan entalpi desorpsi yang tinggi $\left(-74 \quad \mathrm{KJ} / \mathrm{mol} \quad \mathrm{H}_{2}\right)$ sehingga proses hidrogenasi/dehidrogenasi membutuhkan temperatur yang tinggi (> $300{ }^{\circ} \mathrm{C}$ pada 1 bar). Dari segi kinetika, proses perubahan magnesium menjadi magnesium hidrida secara keseluruhan membutuhkan waktu yang lama (secara umum 50 jam) [7]. Upaya untuk memperbaiki sifat-sifat $\mathrm{Mg}$ tersebut telah dilakukan diantaranya: memodifikasi sifat termodinamika menggunakan paduan berbasis $\mathrm{Mg}$, penambahan katalis seperti $\mathrm{Fe}, \mathrm{Ni}, \mathrm{Cu}, \mathrm{Al}$, atau logam oksida. Zat aditif/katalis tersebut mengubah sifat permukaan, struktur mikro dan ukuran butir. Pemaduan logam berbasis $\mathrm{Mg}$ dilakukan dengan teknik mechanical alloying. Keuntungan dari penggunaan teknik mechanical alloying yaitu untuk mempermudah pembentukan beberapa paduan dan hidrida. Hasil pemaduan mechanical alloying berupa $\mathrm{Mg}$ berbasis mikro bahkan nanokristalin dengan dislokasi dan special defects dengan energi yang tinggi untuk mengikat hidrogen [8].

Ball milling merupakan salah satu metode mechanical alloying untuk memperbaiki kinerja serapan magnesium hidrida. Terdapat korelasi antara ball milling dengan sifatsifat serapan material penyimpan hidrogen. Kapasitas penyerapan hidrogen dan laju kinetik meningkat seiring dengan meningkatnya waktu milling. Kapasitas serapan hidrogen meningkat hingga $20 \%$ dengan proses milling selama 20 jam. Akan tetapi setelah mencapai batas maksimum, kapasitas penyerapan dan laju kinetiknya justru menurun. Hal ini dikarenakan adanya unsur pengotor yang menyatu dengan material akibat efek gesekan. Semakin lama waktu ball milling, maka semakin banyak pula gesekan yang terjadi [9]. Upaya untuk menurunkan waktu ball milling dilakukan Zulkarnain [10] yaitu dengan teknik reactive mechanical alloying (RMA). Teknik RMA ini memungkinkan proses penghalusan material dalam periode milling yang singkat dengan bantuan gas hidrogen selama proses berlangsung.

Perubahan fasa selama mechanical alloying dapat mempengaruhi kapasitas penyimpanan hidrogen. Perlakuan panas aniling telah dilakukan untuk menghilangkan tegangan mekanik yang disebabkan milling dan untuk mengganti fasa amorf [11]. Perlakuan panas aniling meningkatkan kapasitas sekitar 2 kali lebih besar dibandingkan pemaduan mechanical alloying tanpa aniling.

Penelitian ini dilakukan untuk memperbaiki sifat $\mathrm{Mg}$ sebagai Penambahan paduan logam Al dan Ti pada paduan logam Mg diharapakan dapat memperbaiki sifat serapan Mg. Pemaduan material dilakukan dengan teknik RMA. Perubahan fasa amorf selama proses RMA menyebabkan adanya tegangan mekanik dan perlakuan panas anil dilakukan untuk menghilangkan tegangan mekanik tersebut. Temperatur optimum pemanasan aniling diharapkan dapat meningkatkan kapasitas dan efektifitas sifat-sifat penyimpanan hidrogen.

\section{Metode Penelitian}

\subsection{Reactive Mechanical Alloying (RMA)}

Pemaduan logam MgAITi dengan teknik RMA dikerjakan menggunakan mesin ball milling. Serbuk logam MgAITi dipadukan dengan komposisi berat $\mathrm{Mg}$, Al dan $\mathrm{Ti}$ yaitu 85 , 15 dan $5 \%$. Rasio berat bola ball milling: serbuk pengerjaan teknik RMA adalah 10:1. Paduan $\mathrm{Mg}_{85} \mathrm{Al}_{15}+\mathrm{Ti}_{5}$ dilakukan dalam glove box yang dialiri gas argon (Ar, high purity) untuk memastikan pengerjaan teknik RMA dalam keadaan inert. Pemaduan teknik RMA dilakukan selama 10 jam dengan kecepatan $900 \mathrm{rpm}$ dan selama proses ke dalam reaksi dialiri gas Hidrogen. Pemaduan dengan teknik RMA dianalisis ukurannya dengan menggunakan alat PSA (Particle Size Analyzer).

\subsection{Perlakuan panas}

Perlakuan panas aniling dimulai dengan memanaskan sampel uji ke dalam tungku pemanas dengan atmosfir argon, variasi temperatur pemanasan yakni 300; 340; dan $380^{\circ} \mathrm{C}$. Sampel ditahan di dalam tungku pemanas selama 2 jam kemudian dibiarkan dalam tungku hingga tempertur kamar.

\subsection{Karakterisasi}

Karakterisasi menyangkut struktur (meliputi komposisi fasa, crystallitesize/peak broadening, microstrain, residual stress) diobservasi dengan menggunakan XRD (Philips PW3710 Diffractometer, radiasi Co-Ka). Kondisi pengukuran: Scantime (33.20), Number of steps (4000), Time per step(0.5) dan Scan speed (0.04). Analisa struktur mikro material dipelajari dengan menggunakan perangkat mikroskop elektron (JEOL JSM-5310LV). Sampel (serbuk) yang akan diobservasi terlebih dahulu dilakukan proses homogenisasi dengan menggunakan gelombang ultrasonik. Masing-masing sampel dilakukan pengamatan morfologi permukaan. Pengujian termal dipelajari dengan perangkat Differential Scanning Calorimetry (DSC) untuk analisis eksoterm dan endoterm. Pengujian DSC dilakukan dalam suasana nitrogen (UHP 99,999\%) dengan flow rate 20 $\mathrm{ml} / \mathrm{min}$ dan heating rate dari $20^{\circ} \mathrm{C}$ hingga $450{ }^{\circ} \mathrm{C}$.

\section{Hasil dan Pembahasan}

\subsection{Ukuran partikel}

Ukuran partikel suatu material sebagai media penyimpan hidrogen akan berpengaruh terhadap penyerapan hidrogren yang terjadi. Hasil pengujian particle size analysis (PSA) sampel $\mathrm{Mg}_{85} \mathrm{Al}_{15}+\mathrm{Ti}_{5}$ yang telah dilakukan reactive mechanical alloying (RMA) selama 10 jam menunjukkan ukuran rata-rata partikel sampel $\mathrm{Mg}_{85} \mathrm{Al}_{15}+\mathrm{Ti}_{5}$ sebesar 13,59 $\mu \mathrm{m}$. Perlakuan reactive mechanical alloying telah mereduksi ukuran partikel material hingga 15 kali lebih halus. Semakin kecil ukuran partikel maka semakin besar luas permukaan sampel. Luas permukaan sampel yang semakin besar dapat meningkatkan jumlah partikel yang terserap. Luas permukaan yang tinggi meningkatkan penyerapan hidrogen, baik secara fisika (penyerapan pada permukaan) maupun penyerapan kimia (penyerapan hingga ke dalam porositas materi) [12].

\subsection{Struktur kristal}

Perlakuan panas (aniling) setelah proses mechanical alloying selama 60 jam dapat merubah fasa amorf material $\mathrm{Mg}_{76} \mathrm{Ti}_{12} \mathrm{Fe}_{4} \mathrm{Ni}_{8}$ menjadi fasa kristal [9]. Proses milling selama 60 jam meningkatkan derajat amorfisasi material yang ditunjukkan dengan melebarnya puncak difraksi pola XRD pada penelitian tersebut. Semakin lama waktu milling maka reduksi materil semakin besar. Reduksi ukuran material akan meningkatkan luas permukaan material terhadap rasio volume butir. Luas permukaan yang besar ini diharapkan akan mempermudah interaksi dan absorbsi hidrogen ke dalam material $\mathrm{Mg}$ sehingga kondisi ini sangat diharapkan pada material penyimpan hidrogen. Lucaci menjelaskan bahwa semakin lama waktu milling kemungkinan timbulnya pengotor juga semakin besar dan semakin lama waktu millimg juga menyebabkan peningkatan derajat amorfisasi.

Teknik RMA telah menjadi salah satu prosedur preparasi sampel material penyimpan hidrogen. Teknik ini mengalirkan gas hidrogen dengan tekanan tertentu ke dalam material $\mathrm{Mg}_{85} \mathrm{Al}_{15}+\mathrm{Ti}_{5}$. Kehadiran gas hidrogen ke dalam reaksi akan mempercepat terjadinya penghalusan material sehingga waktu yang diperlukan untuk milling lebih cepat. Dalam penelitian ini, preparasi sampel teknik RMA dilakukan selama 10 jam. Preparasi teknik RMA material $\mathrm{MgH}_{2}-\mathrm{SiC}$ selama 10 jam dilakukan oleh Zulkarnain [10]. Zulkarnain menyatakan bahwa waktu milling selama 10 jam merupakan waktu yang optimal dalam mereduksi ukuran butir material. 


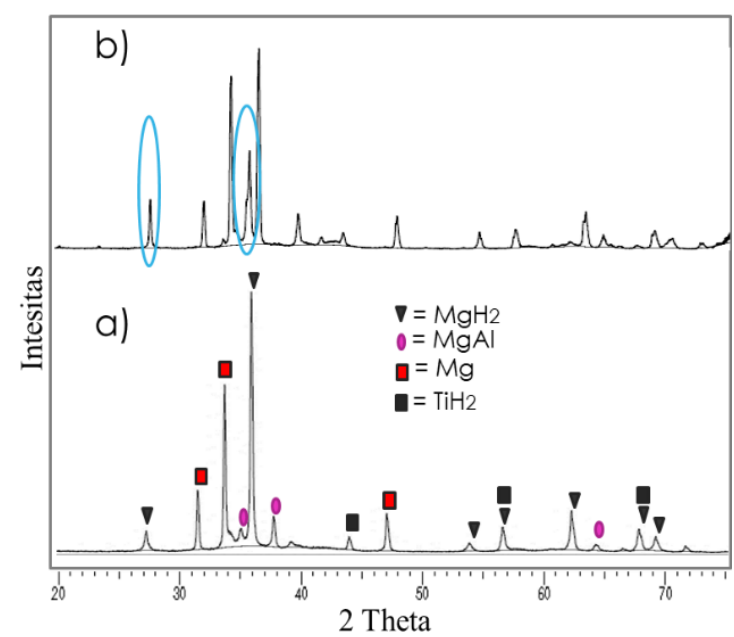

Gambar 1. a) Pola XRD $\mathrm{Mg}_{85} \mathrm{Al}_{15}+\mathrm{Ti}_{5}$ tanpa perlakuan aniling, b) Pola XRD $\mathrm{Mg}_{85} \mathrm{Al}_{15}+\mathrm{Ti}_{5}$ perlakuan aniling temperatur $300^{\circ} \mathrm{C}$

Gambar 1.a) menunjukkan pola difraksi X-ray $\mathrm{Mg}_{85} \mathrm{Al}_{15}+\mathrm{Ti}_{5}$ yang telah dipreparasi dengan teknik reactive mechanical alloying selama 10 jam dan Gambar 1.b) menunjukkan pola difraksi X-ray $\mathrm{Mg}_{85} \mathrm{Al}_{15}+\mathrm{Ti}_{5}$ yang telah dipreparasi dengan teknik reactive mechanical alloying selama 10 jam dan dilanjutkan perlakuan panas aniling temperatur $300^{\circ} \mathrm{C}$. Merujuk literatur pola difraksi X-ray [13], hasil pengamatan pola difraksi X-ray teknik RMA ini menunjukkan kehadiran fasa hidrida $\mathrm{MgH}_{2}$ sebagai fasa utama. Setelah perlakuan panas terjadi perubahan pola difraksi. Perubahan pola paling terlihat pada sudut $2 \theta 35,34$ yaitu puncak MgAl. Perubahan pola difraksi ini diindikasikan akibat perubahan fasa amorf material menjadi fasa kristal. Perlakuan panas aniling memperbaiki sifat-sifat fisik material yang berubah selama proses reactive mechanical alloying sehingga didapatkan struktur kristal yang tersusun rapi. Tahapan ini juga sering disebut rekristalisasi (pengkristalan kembali).

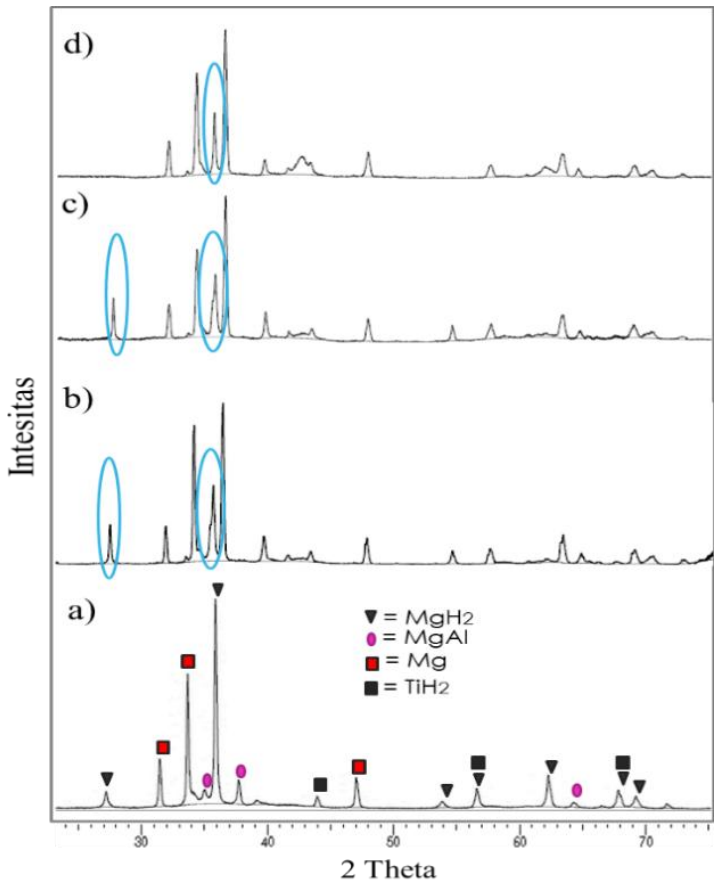

Gambar 2 a) tanpa perlakuan aniling, b) Aniling temperatur $300^{\circ} \mathrm{C}$, c) Aniling temperatur $340^{\circ} \mathrm{C}$ dan d) Aniling temperatur $380^{\circ} \mathrm{C}$
Pengaruh temperatur aniling terhadap media penyimpan hidrogen juga dianalisa berdasarkan pola XRD yang ditunjukkan pada gambar 2. Secara berturut-turut gambar 2 a-d menunjukkan pola difraksi material tanpa perlakuan aniling, aniling dengan pemanasan 300,340 dan $380{ }^{\circ} \mathrm{C}$. Perbedaan pola difraksi paling tampak terlihat pada sudut $2 \theta$ $27,47^{\circ}$ dan $35,34^{\circ}$. Intensitas puncak difraksi $\mathrm{MgH}_{2}$ sudut $2 \theta$ $27,47^{\circ}$ mengalami peningkatan ketika material di aniling pada temperatur 300 dan $340{ }^{\circ} \mathrm{C}$. Pemanasan temperatur aniling hingga $380{ }^{\circ} \mathrm{C}$ justru menghilangkan puncak difraksi $\mathrm{MgH}_{2}$. Berdasarkan pola difraksi tersebut, kesimpulan pertama bahwa temperatur optimal perlakuan panas material penyimpan hidrogen yaitu pada temperatur pemanasan aniling 300 dan $340{ }^{\circ} \mathrm{C}$. Semakin tinggi temperatur pemanasan aniling justru dapat merusak material $\mathrm{MgH}_{2}$ yang akan digunakan. Puncak difraksi sudut $2 \theta \quad 35,34^{\circ}$ menunjukkan senyawa MgAl. Intensitas pada puncak ini cukup tinggi dikarenakan perlakuan panas aniling dapat merekristalisasi senyawa MgAl, terjadi perubahan sampel dari fasa amorf menjadi fasa kristal. Tidak seperti senyawa $\mathrm{MgH}_{2}$ yang ditunjukkan pada pola difraksi sudut $2 \theta 27,47^{\circ}$, pemanasan aniling hingga temperatur $380^{\circ} \mathrm{C}$ tidak merusak senyawa MgAl. Sifat fisik dari masing-masing senyawa baik $\mathrm{MgH}_{2}$ maupun $\mathrm{MgAl}$ yang menyebabkan perbedaan ini. Merujuk referensi data msds senyawa $\mathrm{MgH}_{2}$, titik leleh senyawa $\mathrm{MgH}_{2}$ berada pada kisaran temperatur $300{ }^{\circ} \mathrm{C}$, sedangkan senyawa $\mathrm{MgAl}$ berada pada kisaran $600{ }^{\circ} \mathrm{C}$. Pemanasan di atas temperatur $300{ }^{\circ} \mathrm{C}$ bukan lagi rekristalisasi senyawa $\mathrm{MgH}_{2}$, melainkan pelelehan senyawa tersebut.

\subsection{Struktur Morfologi}

Gambar 3 menunjukkan hasil uji analisis SEM-EDX perbesaran 100 kali material $\mathrm{Mg}_{85} \mathrm{Al}_{15}+\mathrm{Ti}_{5}$ hasil perlakuan RMA dilanjutkan perlakuan panas dengan variasi temperatur. Tingkat homogenitas material dengan perlakuan panas aniling temperatur $300{ }^{\circ} \mathrm{C}$ lebih besar dibandingkan dengan material dengan perlakuan panas pada temperatur $340^{\circ} \mathrm{C}$ dan $380^{\circ} \mathrm{C}$. Pemanasan material hingga temperatur $300{ }^{\circ} \mathrm{C}$ kemudian dilanjutkan holding selama 2 jam telah mampu mengembalikan struktur kristal material. Proses perlakuan panas aniling bertujuan untuk memperbaiki struktur mikro dari material, dalam kasus ini diharapkan terjadinya homogenitas mikrostruktur sehingga mengubah fasa amorf material menjadi fasa kristal.

a)

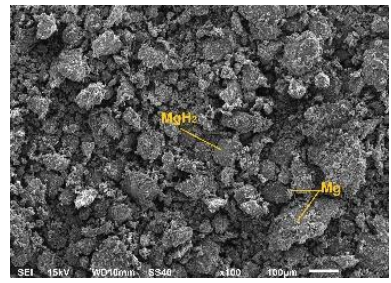

b)
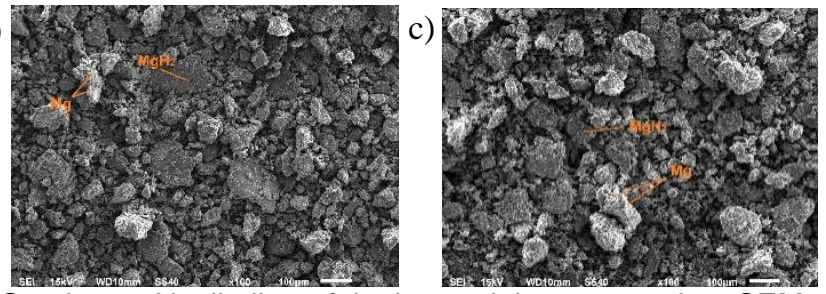

Gambar 3. Hasil uji morfologi material menggunakan SEMEDX perbesaran $100 \mathrm{kali}$, a) Aniling temperatur $300^{\circ} \mathrm{C}$, b) Aniling temperatur $340^{\circ} \mathrm{C}$ dan c) Aniling temperatur $380^{\circ} \mathrm{C}$

Buku ASM Handbook (1991) menuliskan bahwa perlakuan panas aniling material MgAl dilakukan pada temperatur 345 ${ }^{\circ} \mathrm{C}$ [14]. Pemanasan pada temperatur $345{ }^{\circ} \mathrm{C}$ tersebut dilakukan untuk material berupa lempengan, sedangkan material yang digunakan pada penelitian ini berupa serbuk berukuran mikro. Material berupa serbuk memiliki luas permukaan yang lebih besar dibandingkan material dalam 
bentuk lempengan sehingga pengaruh luas permukaan material dimungkinkan menurunkan temperatur austenit dalam diagram fasa MgAl. Semakin besar luas permukaan suatu material maka pergerakan struktur mikro akibat pemanasan akan semakin cepat. Tumbukan yang terjadi semakin cepat dan penataan ulang struktur mikro terjadi di bawah temperatur referensi.

Kenaikan temperatur pemanasan meningkatkan warna terang pada struktur mikro material dalam hal ini adalah semakin meningkatnya jumlah butiran $\mathrm{Mg}$. Pada temperatur $300{ }^{\circ} \mathrm{C}$, hampir seluruh material yang terlihat dari analisis SEM-EDX menunjukkan warna hitam. Pemanasan material hingga temperatur $340{ }^{\circ} \mathrm{C}$ mulai memunculkan warna putih pada permukaan material dan warna putih semakin banyak ketika pemanasan dilakukan pada temperatur $380{ }^{\circ} \mathrm{C}$. Berdasarkan hasil uji XRD, senyawa terbanyak dalam material adalah $\mathrm{MgH}_{2}$. Peningkatan temperatur pemanasan menjadikan senyawa $\mathrm{MgH}_{2}$ melewati garis batas titik leleh senyawa sehingga senyawa akan meleleh dan struktur mikro permukaan material menjadi tidak lagi homogen. Pernyataan ini diperkuat pada temperatur $380^{\circ} \mathrm{C}$, senyawa $\mathrm{MgH}_{2}$ pada sudut $2 \theta 27,47$ menghilang diakibatkan terjadinya pelelehan senyawa $\mathrm{MgH}_{2}$. Hasil analisis XRD dan SEM-EDX menyatakan bahwa temperatur optimal material $\mathrm{Mg}_{85} \mathrm{Al}_{15}+\mathrm{Ti}_{5}$ sebagai media penyimpan hidrogen terjadi pada temperatur pemanasan aniling $300^{\circ} \mathrm{C}$.

Gambar 4 menunjukkan hasil uji analisis SEM-EDX material $\mathrm{Mg}_{85} \mathrm{Al}_{15}+\mathrm{Ti}_{5}$ perbesaran 10.000 kali. Pada pemanasan temperatur aniling $300{ }^{\circ} \mathrm{C}$, tampak kehadiran senyawa $\mathrm{MgH}_{2}$ hasil perlakuan RMA dan beberapa butiran Mg yang bewarna terang.

a)

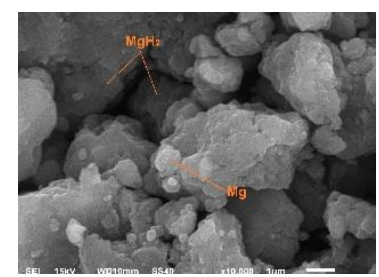

b)
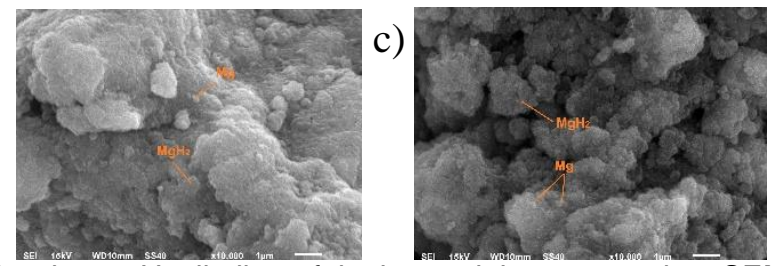

Gambar 3. Hasil uji morfologi material menggunakan SEM-

EDX perbesaran $1000 \mathrm{x}$, a) Aniling temperatur $300^{\circ} \mathrm{C}, \mathrm{b}$ )

Aniling temperatur $340^{\circ} \mathrm{C}$ dan c) Aniling temperatur $380^{\circ} \mathrm{C}$

Butiran Mg menempel pada senyawa $\mathrm{MgH}_{2}$. Kenaikan temperatur aniling meningkatkan jumlah butiran $\mathrm{Mg}$ dan butiran ini semakin menutupi senyawa $\mathrm{MgH}_{2}$. Kenaikan butiran $\mathrm{Mg}$ akan berpengaruh terhadap difusi $\mathrm{H}_{2}$ dalam senyawa $\mathrm{MgH}_{2}$. Difusi atom $\mathrm{H}_{2}$ dapat terjadi ketika energi barrier telah terlampaui. Kenaikan butiran Mg mengakibatkan hidrogenasi dan dehidrogenasi membutuhkan energi yang semakin besar karena energi barrier yang dibutuhkan atom untuk melewati butiran $\mathrm{Mg}$ ini semakin besar. Pengaruh butiran $\mathrm{Mg}$ terhadap dehidrogenasi telah dilaporkan oleh Tanniru et al. berdasarkan hasil penelitian yang dianalisis menggunakan SEM [15]. Mereka menyimpulkan bahwa butiran $\mathrm{Mg}$ berperan dalam pelepasan temperatur hidrogen. Ketika permukaan $\mathrm{MgH}_{2}$ tertutupi oleh butiran $\mathrm{Mg}$, temperatur desorpsinya tinggi. Energi yang diperlukan untuk melewati butiran Mg tinggi. Antasari et al. Juga telah menyampaikan kesulitan pelepasan hidrogen akibat tertutupinya senyawa $\mathrm{MgH}_{2}$ oleh butiran $\mathrm{Mg}$ [16].

\subsection{Uji Termal Material}

Gambar 4 Hasil Uji Termal DSC Sampel, a) Aniling temperatur $300{ }^{\circ} \mathrm{C}$, b) Aniling temperatur $340{ }^{\circ} \mathrm{C}$ dan c) Aniling temperatur $380{ }^{\circ} \mathrm{C}$. Uji termal menggunakan alat DSC dilakukan pada ketiga sampel dengan variasi temperatur aniling. Temperatur desorpsi ( $T$ onset) pada ketiga ssampel dapat dilihat dalam gambar 4 . Terlihat bahwa temperatur desorpsi ketiga sampel masih cukup tinggi, yaitu sekitar $430{ }^{\circ} \mathrm{C}$. Penelitian yang dilakukan oleh Zuettel juga menunjukkan temperatur operasi $\mathrm{MgH}_{2}$ masih tinggi [17]. Penelitian ini dilakukan sebagai upaya menurunkan temperatur operasi $\mathrm{MgH}_{2}$ dengan menambahkan katalis $\mathrm{Al}$ dan $\mathrm{Ti}$.

Reduksi kristal hingga skala mikro bahkan skala nano akan membentuk luas permukaan yang besar, $\mathrm{H}$ akan lebih mudah berdifusi sehingga mengalami penurunan temperatur desorpsi [18] Namun, seperti yang terlihat pada gambar 4.5 temperatur operasi $\mathrm{MgH}_{2}$ masih cukup tinggi, katalis Al dan $\mathrm{Ti}$ tidak memiliki pengaruh yang kuat terhadap penurunan temperatur desorpsinnya. Penjelasan pengaruh logam terhadap ikatan $\mathrm{MgH}_{2}$ menggunakan kalkulasi Density Functional Theory (DFT) dilaporkan oleh [8].

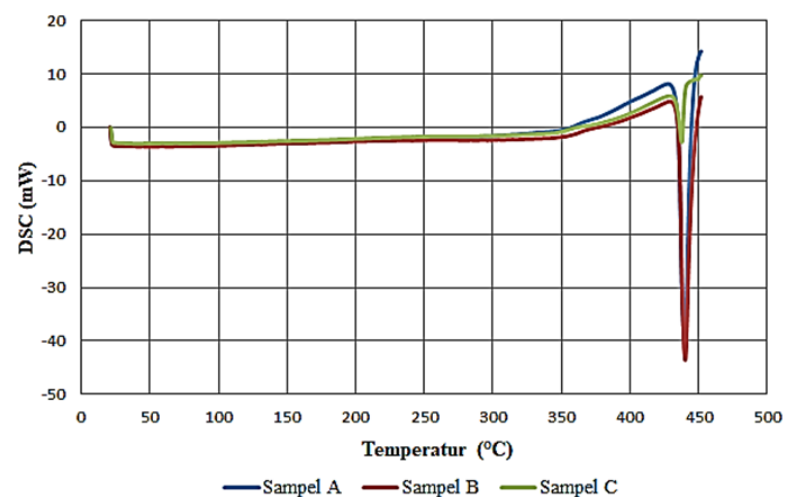

Gambar 4 Hasil Uji Termal DSC Sampel,

a) Aniling temperatur $300^{\circ} \mathrm{C}$, b) Aniling temperatur $340{ }^{\circ} \mathrm{C}$ dan c) Aniling temperatur $380^{\circ} \mathrm{C}$

Berdasarkan hasil pemodelan dapat dievaluasi pengaruh logam pada ikatan $\mathrm{MgH}_{2}$. Logam katalis $\mathrm{Sc}$ dan $\mathrm{Ni}$ menunjukkan aktivitas yang lebih tinggi. Logam Sc berkontribusi besar terhadap donasi elektron elektron dari orbital-orbital ikatan $\mathrm{MgH}_{2}$, yang mengakibatkan donasi $\mathrm{Mg}$ $\mathrm{H}_{2}$ menjadi lebih mudah. Sebaliknya logam $\mathrm{Ni}$ yang kedudukannya lebih tinggi berkontribusi besar kepada back donation elektron-elektron antibonding $\mathrm{MgH}_{2}$ sehingga disosiasi $\mathrm{MgH}_{2}$ lebih mudah. Penelitian ini menggunakan katalis $\mathrm{Al}$ dan $\mathrm{Ti}$ dimana sifat dari kedua atom tersebut sebagai donatur elektron. Katalis Al dan Ti berkontribusi terhadap donasi elektron dari orbital-orbital ikatan $\mathrm{MgH}_{2}$. Sedangkan pada sisi sebaliknya tidak ada pengembalian donasi eletron oleh suatu unsur ke dalam orbital $\mathrm{MgH}_{2}$ mengakibatkan disosiasi $\mathrm{MgH}_{2}$ tidak mudah. Gambar 4 juga menunjukkan bahwa variasi temperatur aniling tidak berpengaruh secara signifikan terhadap temperatur desorpsi. Aktifitas katalis terhadap disosiasi ikatan $\mathrm{Mg}-\mathrm{H}_{2}$ lebih menentukan penurunan temperatur desorpsi dibandingkan pengaruh temperatur aniling.

\section{Simpulan}

Sifat serapan Mg sebagai material penyimpan hydrogen dengan penambahan katalis $\mathrm{Al}$ dan $\mathrm{Ti}$ dilakukan menggunakan teknik reactive mechanical alloying (RMA) dapat memperbaiki material penyimpan hidrogen. Perlakuan RMA dengan variasi temperatur aniling pada 300,340 dan $380{ }^{\circ} \mathrm{C}$ menunjukkan kehadiran fasa hidrida $\mathrm{MgH}_{2}$ sebagai fasa utama dan mendapatkan temperatur aniling optimal 
material $\mathrm{Mg}_{85} \mathrm{Al}_{15}+\mathrm{Ti}_{5}$ yaitu $300{ }^{\circ} \mathrm{C}$. Adapun kajian aktivitas katalis sebagai donatur dan acceptor elektron dapat dijadikan bahan material penyimpan hidrogen yang optimal untuk menentukan disosiasi ikatam $\mathrm{Mg}-\mathrm{H}_{2}$.

\section{Ucapan Terima Kasih}

Penulis mengucapkan terimakasih kepada semua pihak atas terselesaikannya penelitian dan artikel ini. Penulis mengucapkan terimakasih kepada Ristekdikti selaku penyedia dana, Politeknik Manufaktur Ceper dan Universitas Indonesia yang telah memfasilitasi sarana dan prasarana selama penelitian ini berlangsung. Penulis juga mengucapkan terima kasih pada Dr. Arridina Susan Silitonga, S.T., M.Eng atas bantuan pelatihan penulisan karya ilmiah nasional.

\section{Daftar Pustaka}

[1] R. P. O. Hayre, S.-W. Cha, W. G. Colella, and F. B. Prinz, Fuel Cell Fundamentals. John Wiley \& Sons. Inc, 2019.

[2] J. Suls, "The Mechanics of Metal Hydride Hydrogen Storage Systems for Portable Applications," in Proceeding of Fuel Cells Final Project, 2014.

[3] A. R. V. Babu, N. Devunuri, D. R. Manisha, Y. Prashanthi, R. Merugu, and A. J. R. R. Teja, "Magnesium Hydrides for Hydrogen Storage: A Mini Review," Int. J. ChemTech Res., vol. 6, no. 7, pp. 3451-3455, 2014.

[4] P. Prachi's, W. Mahesh, and G. Aneesh, "A Review on Solid State Hydrogen Storage Material," Adv. Energy Power, vol. 4, no. 2, pp. 11-22, 2016.

[5] M. Lotoskyy et al., "An outstanding effect of graphite in nano- $\mathrm{MgH}_{2}-\mathrm{TiH}_{2}$ on hydrogen storage performance," $\mathrm{J}$. Mater. Chem. A View, no. 16, pp. 1-16, 2018.

[6] A. Ranjbar et al., "Hydrogen storage properties of $\mathrm{MgH}_{2}$ - SiC composites," Mater. Chem. Phys., vol. 114, pp. 168-172, 2009.

[7] B. Sakintuna, F. Lamari-darkrim, and M. Hirscher, "Metal hydride materials for solid hydrogen storage: A review," Int. J. Hydrogen Energy, vol. 32, pp. 11211140, 2007.

[8] J. Crivello, T. Nobuki, and T. Kuji, "Improvement of MgAl alloys for hydrogen storage applications Improvement of $\mathrm{Mg}-\mathrm{Al}$ alloys for hydrogen storage applications," Int. J. Hydrogen Energy, vol. 34, pp. 1937-1943, 2014.

[9] H. Yuan, Y. An, G. Xu, and C. Chen, "Hydriding behavior of magnesium-based hydrogen storage alloy modified by mechanical ball-milling," Mater. Chem. Phys. 83, vol. 83, pp. 340-344, 2004.

[10] Zulkarnain, "Material Penyimpan Hidrogen Sistem $\mathrm{MgH}_{2}$-SiC yang dipreparasi melalui rute Reactive Mechaical Alloying," Universitas Indonesia, 2011.

[11] M. Lucaci, A. R. Biris, R. L. Orban, G. B. Sbarcea, and V. Tsakiris, "Effects of mechanical alloying on the hydrogen storage properties of the $\mathrm{Mg}_{76} \mathrm{Ti}_{12} \mathrm{Fe}_{12}{ }_{\mathrm{x}} \mathrm{Ni}_{\mathrm{x}}(\mathrm{x}$ $=4,8$ ) materials," J. Alloys Compd., vol. 488, pp. 163168, 2009.

[12] X. Yu, Z. Tang, D. Sun, L. Ouyang, and M. Zhu, "Progress in Materials Science Recent advances and remaining challenges of nanostructured materials for hydrogen storage applications," Prog. Mater. Sci., vol. 88, pp. 1-48, 2017.

[13] Y. Wang, S. Lu, Z. Zhou, W. Zhou, J. Guo, and Z. Lan, "Effect of transition metal on the hydrogen storage properties of Mg-Al alloy," J. Mater. Sci., vol. 52, pp. 2392-2399, 2017.

[14] Stevenson, "Heat Treating of Magnesium Alloys (on ASM Handbook Volume 4 Heat Treating)," ASM Handbook Committee, 1991.
[15] M. Tanniru, H. Tien, and F. Ebrahimi, "Study of the dehydrogenation behavior of magnesium hydride," Scr. Mater., vol. 63, pp. 58-60, 2010.

[16] M. V. Antisari, A. Montone, A. Aurora, M. R. Mancini, D. M. Gattia, and L. Pilloni, "Intermetallics Scanning electron microscopy of partially de-hydrogenated $\mathrm{MgH}_{2}$ powders," Intermetallics, vol. 17, no. 8, pp. 596-602, 2009.

[17] Z. Yanghuan, Z. Tingting, Y. Tai, and Y. Zeming, "Improved Hydrogen Storage Kinetics of Nanocrystalline and Amorphous $\mathrm{Mg}-\mathrm{Nd}-\mathrm{Ni}-\mathrm{Cu}-$ based $\mathrm{Mg}_{2} \mathrm{Ni}$-type Alloys by Adding $\mathrm{Nd}$," J. Wuhan Univ. Technol. Sci. Ed., vol. 30, no. 6, pp. 1115-1124, 2015.

[18] R. A. Varin and L. Zbroniec, "The effects of ball milling and nanometric nickel additive on the hydrogen desorption from lithium borohydride and manganese chloride $\left(3 \mathrm{LiBH}_{4}+\mathrm{MnCl}_{2}\right)$ mixture," Int. J. Hydrogen Energy, vol. 35, no. 8, pp. 3588-3597, 2010. 